VOX PATRUM 35 (2015) t. 64

Piotr O. SCHOLZ*

\title{
MISJA I MONASTYCYZM MANICHEJSKI W DOLINIE NILU I JEGO WPLYW NA TAMTEJSZE CHRZEŚCIJAŃSTWO NA PRZEŁOMIE III/IV WIEKU
}

\author{
„Non enim putetis, fratres, \\ quia potuerunt fieri haereses per aliquas parvas animas: \\ non fecerunt haereses nisi magni homines"1.
}

Jest dzisiaj prawie niewyobrażalne mówienie o wczesnym chrześcijaństwie bez wzmianki o manicheizmie ${ }^{2}$, ze względu na jego wymiar i siłę konkurencyjną wobec chrześcijaństwa w okresie zmodyfikowanego pojęcia Achsenze$i t^{3}$, czyli na „pograniczu epok” (dosłowne thumaczenie „czas osi”), pomiędzy późnym antykiem a narodzeniem się islamu, i to na tak poważnym obszarze starych kultur, siegających na wschodzie po Chiny i na zachodzie po „słupy Herkulesa", znane dzisiaj lepiej pod toponimem Gibraltar (Dżebel el Tarik) ${ }^{4}$.

* Dr hab. Piotr O. Scholz, prof. UMCS - profesor nadzwyczajny w Zakładzie Porównawczej Historii Sztuki w Instytucie Kulturoznawstwa na Wydziale Humanistycznym Uniwersytetu Marii Curie-Skłodowskiejw Lublinie, e-mail: zphs@vp.pl.

${ }^{1}$ Augustinus, Enarrationes in Ps. 124, 5, PL 37, 1652.

${ }^{2}$ Por. krótkie encyklopedyczne zarysy tej problematyki: H.-J. Klimkeit, Mani, Manichäismus, LThK $^{3}$ VI 1265-1269; A. Böhlig, Manichäismus, TRE XXII 25-45; A. Böhlig - J. van Oort, Manichaeism, w: Dictionary of Gnosis \& Western Esotericism, ed. W.J. Hanegraaff, Leiden 2006, 756-765; A. Böhlig, Mani, Manichäismus, $\mathrm{RGG}^{4}$ V 732-741; M. Hutter, Manichäismus, RACh XXIV 6-48; S. Lieu, Manichaeism, w: Late Antiquity: A Guide to the Postclassical World, ed. G.W. Bowersock - P. Brown - O. Grabar, Harvard 1999, 555n. Niestety polski artykuł autorstwa Romana Szmurło (EK XI 1143-1148) nie odpowiada obecnemu stanowi wiedzy, nie mówiąc już o fakcie używania zantykizowanej - dzisiaj w zasadzie już niestosowanej - formy imienia Maniego

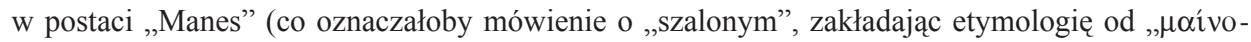
$\mu \alpha \imath ")$. W tym względzie należy uznać nieco mniejszy artykuł w Encyklopedii Kościoła (na bazie The Oxford Dictionary of the Christian Church z 1997) za kompetentniejszy - por. Encyklopedia Kościoła, ed. F.L. Cross - E. A. Livingstone, t. 2, tłum. E. Czerwińska i in., Warszawa 2004, 158-160. Mimo przeszło półwiecza jakie minęło od ukazania się monografii G. Widengrena (Mani und Manichäismus, Stuttgart 1961) stanowi ona ciągle świetną syntezę tego gnostyzującego kierunku wczesnego chrześcijaństwa. Por. również M. Tardieu, Manichéisme, Paris 1981.

${ }^{3}$ Por. K. Jaspers, Vom Ursprung und Ziel der Geschichte, Frankfurt am Main 1955, 14-31.

${ }^{4}$ Obecność manichejczyków w Hiszpanii potwierdzają listy Leona Wielkiego z 447 r., por. 
Jednocześnie nie można zapominać, że obok św. Augustyna (354-430) cała plejada wcześniejszych (szczególnie z kręgu judeo-chrześcijańskiego) i późniejszych chrześcijan zauroczona była manichejskim gnostycyzmem, jego wizualizacja, fascynującymi opowiadaniami i przypowieściami, które po dziś dzień odnajdujemy w szacie „Baśni tysiąca i jednej nocy”, baśni braci Grimm, czy też w słowiańskiej, bałtyckiej i skandynawskiej tradycji ludowej, co notabene potwierdziły już w latach trzydziestych ubiegłego stulecia badania Wilhelma Banga-Kaupa ${ }^{6}$.

Faktem trudnym do zanegowania i niemal już powszechnie przyjętym, mimo że wciąż dyskutowanym, zdaje się być również kwestia narodzin ikoniczności wczesnochrześcijańskiej w kręgach gnostycznych, szczególnie manichejskich. Mani (216-276) jest bowiem m.in. autorem jedynej w swoim rodzaju ilustrowanej i komentowanej słowem księgi „Ardhâng”, czyli swoistej „obrazkowej ewangelii”, mającej tym samym charakter żywotny w sensie ciagłej aktualności (das lebendige Evangelium) - niestety do naszych czasów niezachowanej ${ }^{7}$. Ponadto wiele oryginalnych i liturgicznych tekstów manicheizmu ${ }^{8}$ zawiera wypowiedzi motywujące konieczność uwzględnienia ikoniczności w krzewieniu wiary. Tezy sformułowane przeze mnie na uppsalskiej konferencji nubiologicznej $(1986)^{9}$ znalazły pełne potwierdzenie w poszukiwaniach znanego niemieckiego patrysty i historyka wczesnego chrześcijaństwa Christopha Markschiesa ${ }^{10}$. Zdaje się on skłaniać ku mojej tezie, iż chrześcijańska ikoniczność rodzi się na gruncie manicheizmu i jest jego integralną częścią. Nie inaczej widzi to jeden z czołowych badaczy problemu,

R. Schippers, Manichaeans in Spain, w: Studia Manichaica: Proceedings of the IV International Conference of Manichaean Studies, Berlin 1997, ed. R.E. Emmerick - W. Sundermann - P. Zieme, Berlin 2000 (= StMani 4), 511-516.

${ }^{5}$ Por. J. van Oort, Augustine and Manichaeism in the Latin West, Leiden - Boston 2001; V.H. Drecoll - M. Kudella, Augustinus und der Manichäismus, Tübingen 2012.

${ }^{6}$ Por. W. Bang-Kaup, Manichäische Erzähler, Berlin 1931. Zob. też niżej nota 49.

${ }^{7}$ Por. P. Nagel, ZQГPAФEIN und das ,Bild” des Mani in den koptisch-manichäischen Texten, w: Eikon und Logos. Beiträge zur Erforschung byzantinischer Kulturtraditionen, Konrad Onasch zur Vollendung des 65. Lebensjahres, hrsg. H. Goltz, Halle an der Saale1981, 199-238; inaczej W. Sundermann (Was the „Ardahang” Mani's picture book?, „Manichaean Studies” 5 (2005) 373-84) poddaje on w wątpliwość ikoniczny charakter tego pisma, co jednak nie znajduje akceptacji innych autorów. M. Hutter (Die Bedeutung des syrischen Christentums für die gnostische Religion Manis, w: Religionsgeschichte Syriens, hrsg. P.W. Haider - M. Hutter - S. Kreuzer, Stuttgart 1996, 261-272, fig./Abb. 112 na str. 262) podkreśla nie tylko istotę obrazu w manicheizmie, ale daje też przykłady bardzo wczesnego obrazowania samej osoby Maniego.

${ }^{8}$ Por. np. Manichaeae homiliae 18, 5; 25, 5; 27, 20; 28, 16; Kephalaia 44 [113, 26 - 115, 3]; 92 [234, 25 - 236, 6B-F].

${ }^{9}$ Por. P.O. Scholz, Gnostische Elemente in der nubischen Wandmalereien: Das Christusbild, „Nubica“ 1-2 (1987/1988) 565-584.

${ }^{10}$ Por. Ch. Markschies, Gnostische und andere Bilderbücher in der Antike, ZACh 9 (2005) $100-121$. 
religioznawca Manfred Hutter, którego zdanie pozwolę sobie tutaj - ze względu na jego doniosłość - w oryginalnym brzmieniu przytoczyć:

„Fragt man nach der Funktion der Visualisierung, so darf der katechetisch-didaktische Aspekt nicht übersehen werden. Auf die liturgische Verwendung des Bilderbandes weisen koptische Texte hin, wobei das Bild im Kult nicht nur die Lehre illustriert, sondern durch die bildliche Darstellung im Kult den Kampf des Lichtes gegen die Finsternis und die Läuterung des Lichtes aus der Finsternis zugleich aktualisiert. Daher ist die manichäische Ästhetik nicht nur Kunst, sondern eine Arznei, die gleich wie das geschriebene Wort, die Erlösung aus der Welt der Finsternis bringt (ManichPs 46, 23-32. Allb.)"'11.

$\mathrm{Z}$ tych względów jest zrozumiałym, dlaczego sam Mani był wielokrotnie przedstawiany - można by nawet przyjąć, iż stworzył swój autoportret, kopiowany później wielokrotnie i propagowany wśród zwolenników. Mimo że bogata ikoniczność manichejska została w dużej mierze zniszczona - nie tylko przez chrześcijan, ale i przez przedstawicieli innych religii nastawionych wrogo do tej agresywnej i ekspandującej gnostyckiej sekty - to jednak zachowało się także wiele przykładów ilustrowanych książek, jak i malarstwa ściennego (szczególnie w dolinie Turfan w Azji Centralnej) ${ }^{12}$. Rozprzestrzeniający się szczególnie w omawianym tutaj regionie północno-wschodniej Afryki islam wyeliminował bodajże wszelkie ślady manichejskiej ikoniczności (w każdym bądź razie w świetle obecnego stanu wiedzy). W całym Oriencie zachowały się jednak jego liczne fragmenty.

Przed laty w Toronto (ok. 1985) miałem możliwość sfotografować w prywatnych zbiorach mozaikowy wizerunek (il. 1) postaci reprezentującej przypuszczalnie samego Maniego ${ }^{13}$. Mozaika ta pochodzi przypuszczalnie z kręgu eddesańskiego i może być datowana na początek IV w., jeśli nie nawet na koniec III w. Z tego kręgu pochodzą dość wczesne źródła, m.in. Acta Archelai

${ }^{11}$ Hutter, Die Bedeutung des syrischen Christentums, s. 15. W polskim thumaczeniu: „Pytając o funkcję wizualizacji nie można pominąć jej katechetyczno-dydaktycznego aspektu. Na liturgiczne użycie ilustrowanej księgi wskazują teksty koptyjskie, przy czym rola obrazu w kulcie polega nie tylko na ilustracji nauczania, ale i aktualizacji walki światła z ciemnością za pomocą przedstawień ikonicznych. Jednocześnie oczyszczająca moc światła wyłania się z czeluści mroku. Dlatego manichejska estetyka nie jest wyłącznie sztuką, lecz także lekarstwem, które na równi ze słowem pisanym przynosi zbawienie świata z głębokiej ciemności [zła] (ManichPs 46, 23-32, Allb. = A Manichaean Psalm-Book, ed. Ch.R.C. Allbery, Stuttgart 1938)", thum. własne.

${ }^{12}$ Malarstwo i sztuka manichejczyków została w syntetyzującej formie omówiona w: H.-J. Klimkeit, Manichaean art and calligraphy, Iconography of Religions 20, Leiden 1982. Por. również Markschies, Gnostische und andere Bilderbücher, s. 117-119; Z. Gulácsi, Mediaeval Manichaean book art, Leiden - Boston 2005.

${ }^{13}$ Były to zbiory jednego ze znanych kolekcjonerów sztuki starożytnej Elie Borowskiego (1913-2003), stanowiące podstawę założonego później przez niego Museum of Bible Lands w Jerozolimie. Por. również S. N.C. Lieu, A new figurative representation of Mani?, w: StMani 4, s. 380-386. 
prezentujące dysputę pomiędzy Manim a biskupem Archelaosem w roku 270, mająca przypuszczalnie miejsce w Carrhae (obecnie Harran w Turcji) ${ }^{14}$, czyli w orbicie wpływów edessańskich ${ }^{15}$.

Syryjska przestrzeń kulturowa, w której chrześcijaństwo triumfowało wraz ze swoją bogatą literaturą i sztuką ${ }^{16}$, była również dla tego nowego prądu gnostyckiego u jego zarania, kiedy też powstawało piśmiennictwo manichejskie ${ }^{17}$, jedną z najważniejszych. W przeciwieństwie do wielu badaczy, nie jestem jednak skłonny widzieć w manicheizmie expressis verbis nowej religii ${ }^{18}$, nie znaczy to jednak, by nie można było mówić o „kościele manichejskim” (ecclesia manichaica), chociażby ze względu na organizacyjne podobieństwo ${ }^{19}$.

Mani, mawiający: Jam apostot Jezusa Chrystusa (Kephalaia), uważał się za wyznawcę religii chrześcijańskiej, mało tego - niemalże za wcielenie Chrystusa w sensie imitatio Christi; dlatego też częścią składową jego systemu stała się chrystologia. Jego chrystologia, usystematyzowana w długo nieznanej dysertacji Eugena Rose'go (1941, opublikowanej dopiero w 1979) ${ }^{20}$, stanowi

\footnotetext{
${ }^{14}$ Por. J.D. BeDuhn - P. Mirecki, Frontiers of faith. The Christian encounter with Manichaeism in the Acts of Archelaus, Leiden 2007; czy tym samym niniejszy fragment mógł należeć do popularnych w tym czasie przedstawień dysput filozoficznych, np. w Museo Nazionale w Neapolu czy w Villa Albani w Rzymie (por. K. Gaiser, Das Philosophenmosaik in Neapel. Eine Darstellung der platonischen Akademie, Heidelberg 1980), musi pozostać kwestią otwartą. Stylistycznie zwracają na siebie uwagę mozaiki edessańskie (niestety po części zniszczone), datowane na koniec II początek III w., por. J. Rumscheid, Familienbilder im Haus der Ewigkeit. Zu Grabmosaiken aus Edessa, w: Edessa in hellenistisch-römischer Zeit, hrsg. L. Greisiger - C. Rammelt - J. Tubach, Beiruter Texte und Studien 116, Beirut 2009, 255-265, tabl. 2-4 na s. 372nn.

${ }^{15}$ Por. A.F.J. Klijn, Edessa, die Stadt des Apostels Thomas, Neukirchen 1965; w tym kontekście szczególnie istotny przyczynek: Hutter, Die Bedeutung des syrischen Christentums, s. 270n. Zob. W. Pratscher, Geschichte des syrischen Christentums bis zum Beginn des 7. Jahrhunderts, w: Religionsgeschichte Syriens, hrsg. P.W. Haider - M. Hutter - S. Kreuzer, Stuttgart 1996, 273-284.

${ }^{16}$ Por. K. Pinggera, Syrien. I. Geschichte, w: Kleines Lexikon des Christlichen Orients, hrsg. H. Kaufhold, Wiesbaden 2007, 450-451; A. Schmidt, Syrische Literatur, w: Kleines Lexikon des Christlichen Orients, s. 468-474; J. Pahlitzsch - S.P. Brock, Christliche Literatur (in Syrien), RGG ${ }^{4}$ VII 2001-2005. Zob. N.W. Pigulewska, Kultura syryjska we wczesnym średniowieczu, Warszawa 1989; P.O. Scholz, Syria (sztuka), EK XVIII 1365-1368.

${ }^{17}$ Por. Böhlig, Manichäismus, TRE XXII 25-45 (z obszerną wiodącą literatura), spec. 35-37. Aktualnie są wydawane dwie serie: Dictionary of Manichaean Text i Corpus Fontium Manichaeorum, mające objać całe piśmiennictwo manichejskie. Do jakiego stopnia mamy tu do czynienia z ruchem gnostyckim, por. P. Nagel, Über das Verhältnis von Gnosis und Manichäismus, oder: wie gnostisch ist die Gnosis von Mani?, w: Vom „Troglodytenland” ins Reich der Scheherazade. Archäologie, Kunst und Religion zwischen Okzident und Orient, hrsg. M. Długosz, Berlin 2014, 121-140.

${ }^{18}$ Tę tezę postawił swego czasu F.Ch. Baur (Das manichäische Religionssystem, Tübingen 1831) i jest ona przez wielu badaczy i autorów bezdyskusyjnie przyjęta; reprezentował ją i poszerzył na wszelkie zjawiska związane z gnostycyzmem K. Rudolph, Die Gnosis. Wesen und Geschichte einer spätantiken Religion, Leipzig 1977, 356-357 (polskie wydanie: K. Rudolph, Gnoza. Istota $i$ historia późnoantycznej formacji religijnej, tłum. G. Sowiński, Kraków 1995).

${ }^{19}$ Por. Böhlig, Manichäismus, TRE XXII 37-38.

${ }^{20}$ E. Rose, Die manichäische Christologie, Wiesbaden 1979.
} 
istotny wkład do zrozumienia manicheizmu jako jednego z najwcześniejszych gnostyzujących kierunków heretyckiego chrześcijaństwa. Od tego czasu badania nad funkcją i znaczeniem Jezusa w manicheizmie zostały znacznie dalej posunięte, uwzględniają one również m.in. zależności od źródeł biblijnych, co odzwierciedla w swym syntetyzującym artykule Majella Franzmann ${ }^{21}$.

Jak powszechnie wiadomo, Egipt był jednym z krajów, w których manicheizm osiagał szczególny rozwój. Stanowi to świetną wskazówkę i dowód potwierdzany przez obecny stan badań, iż wszędzie tam, gdzie dotarło chrześcijaństwo, przybyli wkrótce manichejczycy, będący niejako jemiołą na drzewie religii Chrystusowej. Bez rozprzestrzeniającej się ewangelii Jezusa Chrystusa nowa nauka Maniego nie zyskałaby zbytniego zrozumienia, dlatego można mówić o swoistej gnostycznej rewizji chrześcijańskiej prawdy. Mani uważając się za apostoła Jezusa Chrystusa zdaje się czynić to samo, co apostoł Paweł, którego określenie przyjmuje, wychodzi jednak z innej niż Paweł pozycji, niemniej zdobywa wielu wyznawców, m.in. Augustyna ${ }^{22}$.

Oczywiście, ta wyjątkowa sytuacja Egiptu wynika ze specyfiki tego kraju jako świetnego archiwum, w którym znaleziony materiał mógł przetrwać do naszych czasów, co gdzie indziej byłoby niewyobrażalne. Niewiele jest bowiem miejsc na świecie o tak suchym, sprzyjającym konserwacji klimacie, jak piaski egipskie - zachowane w nich papirusy stały się podstawą papirologii ${ }^{23}$. Podobny był chyba tylko pustynny klimat Turfanu i Dunhuang w Azji Centralnej, co odbiło się korzystnie na zachowanych tam bogatych źródłach manichejskiej ikonografii i literatury ${ }^{24}$. Dlatego być może jest pewną hybris podkreślanie roli Egiptu jako szczególnie ulubionego kraju manichejczyków. Jeśli jednak tak było, to znaleźli tu oni znakomite możliwości rozwoju i podatny grunt dla swojej działalności misyjnej. Egipt był jedną z istotniejszych domen Imperium Romanum o stosunkowo dużej populacji, która bardzo wcześnie przyjęła chrześcijaństwo, dając możliwość daleko idących sukcesów misyjnych, związanych również z egzystencją poważnej diaspory żydowskiej w dolinie Nilu ${ }^{25}$.

${ }^{21}$ M. Franzmann, Jesus in the Manichaean writing - work in progress, w: StMani 4, s. 220-246.

${ }^{22}$ Por. Rose, Die manichäische Christologie, s. 30-31. Szczególnie istotny artykuł odnośnie popularności manicheizmu jako „pobożności Chrystusowej”. Zob. E. Feldmann, ChristusFrömmigkeit der Mani-Jünger. Der suchende Student Augustinus in ihrem „Netz”?, w: Pietas, Festschift Bernhard Kötting, hrsg. E. Dassman - K.S. Frank, Münster (Westfalen) 1980, 198-216.

${ }^{23}$ Por. W. Schubart, Einführung in die Papyruskunde, Berlin 1918; A. Świderek, Kiedy piaski egipskie przemówity po grecku, Warszawa 1950; P.W. Pestman, The new Papyrological Primer, Leiden 1940; A. Łukaszewicz, Świat papirusów, Warszawa 2001.

${ }^{24}$ Por. A. von Lecoq, Die buddhistische Spätantike im Mittelasien, I-VII, Berlin 1922-1933; tenże, Auf Hellas Spuren in Ostturkistan, Berlin 1926; M. Yaldiz, Archäologie und Kunstgeschichte Chinesisch-Zentralasiens (Xinjiang), Leiden 1987; H.J. Klimkeit, Gnosis and the Silk Road, San Francisco 1993.

${ }^{25}$ Por. J. Mélèze Modrzejewski, Les juifs d'Égypte de Ramsès II à Hadrien, Paris 1992 (por. 
Naukowe badania nad manicheizmem, mające za sobą już przeszło 300 lat ${ }^{26}$, są wciąż intensyfikowane, nie tylko w kręgu International Association of Manichaean Studies, ale i w ramach wielu centrów studiów nad późnym antykiem i wczesnym chrześcijaństwem, reprezentowanych jednak niestety w niewielkim stopniu na ziemi polskiej ${ }^{27}$. Od czasów odkrycia i publikacji Kephalaii $^{28}$ - koptyjskiego manuskryptu manichejskiego opowiadającego nie tylko o życiu tego partyjskiego gnostyka, ale i o jego doktrynie, zakupionego w 1930 r. przez Carla Schmidta (1868-1938) ${ }^{29}$ w konwolucie manuskryptów koptyjskich z Medinet Maadi - znaleziono szereg dalszych kodeksów, wśród których tzw. grecki Kölner Mani-Codex [= CMC] odgrywa szczególną rolę ${ }^{30}$. Do tego dochodzą także pisma ze słynnej biblioteki odkrytej $1991 \mathrm{r}$. w pobliżu Ismant el-Kharab (starożytne Kellis) w egipskiej oazie Dachla ${ }^{31}$, opiewające na więcej jak 3000 fragmentów syryjskich i koptyjskich tekstów manichejskich, z których jeszcze wiele czeka na publikację. Fakt, że zajmie ona jeszcze nieco czasu nie wymaga komentarza, jeśli przypomnimy sobie jak długo trwało wydawanie tekstów z Nag Hammadi ${ }^{32}$ (szczególnie jeśli przyjmiemy, że do tych pism należała również dopiero niedawno opublikowana apokryficzna Ewangelia Judasza ${ }^{33}$ ).

również angielska edycja: The Jews of Egypt: From Rameses II to Emperor Hadrian, transl. Robert Cornman, Princeton 1997 i zawarta tam bibliografia).

${ }^{26}$ Co prawda już w XVI w. Cyriacus Spangenberg napisał historię manicheizmu (Historia Manichaeorum, Vrsellis1578), ale krytyczno-naukowe podejście do tematu podjął dopiero G. Arnold w swojej Unparteyische Kirchen- und Ketzerhistorie (Franckfurt am Mayn 1699/1700) i tuż po nim Isaac de Beausobre, Histoire critique de Manichée et du Manichéisme (Amsterdam 1734-1739).

${ }^{27}$ Por. W. Myszor, Manichejskie pisma, SWPW 146-149; Marek Starowieyski w swoich pierwszych i bardzo istotnych edycjach Apokryfów Nowego Testamentu (Kraków 2007) uwzględnia piśmiennictwo manichejskie omawiane m.in. przez ks. W. Myszora; zob. również M. Stachura, Heretycy, schizmatycy i manichejczycy wobec cesarstwa rzymskiego (lata 324-428, wschodnia część Imperium), Kraków 2000.

${ }^{28}$ Ed. H.J. Polotsky - A. Böhlig, Kephalaia, Stuttgart 1940.

${ }^{29}$ Por. Carl-Schmidt-Kolloquium an der Martin-Luther-Universität 1988, hrsg. P. Nagel, Halle an der Saale 1990; P. Nagel, Schmidt Carl, w: Neue Deutsche Biographie, Bd. 23, München 2007, 200-201 (bibliografia).

${ }^{30}$ Por. A. Heinrichs - L. Koenen, Ein griechische Mani-Codex, Bonn 1970, 97-216; zob. też popularne i łatwo dostępne wydanie: Mani. Auf den Spuren einer verschollenen Religion, hrsg. L. Koenen - C. Römer, Freiburg im Breisgau 1993, 43-103.

${ }^{31}$ Por. I. Gardner, „He has gone to the monastery...”, w: StMani 4, s. 247-257.

${ }^{32}$ The Nag Hammadi library, ed. J.M. Robinson, Leiden 1984; oprócz tej popularnej edycji istnieją niemalże we wszystkich językach tłumaczenia naukowe i popularne (niestety nie zawsze krytyczne). Polska redakcja niektórych tekstów z Nag Hammadi znalazła się również w godnej podziwu edycji Apokryfów Nowego Testamentu ks. M. Starowieyskiego (Kraków 2007). Por. też W. Myszor, Znaczenie tekstów z Nag Hammadi w badaniach pierwotnego chrześcijaństwa, „Acta Universitatis Nicolai Copernici. Nauki Humanistyczno-Społeczne. Historia” 27 (1992) 159-164.

${ }^{33}$ Moim zdaniem najlepsze krytyczne ustosunkowanie się do tekstu, jak i do samej „ewangelii”, prezentuje P. Nagel, Das Evangelium des Judas - zwei Jahre später, ZNW 100 (2009) 101-138; 
Nie ma jakiejkolwiek wątpliwości co do aktywnej działalności misjonarzy manichejskich, którzy przybyli do Egiptu najpóźniej w 260 r. Od dawna znane są nawet niektóre z ich imion: Tomasz, Pappos ${ }^{34}$, Gabryab, Akowas i Hermeias ${ }^{35}$. Kwestią otwartą pozostaje przynależność Skythianosa do manichejczyków, co sugerują daleko idące kontakty i świetna siatka organizacyjna tego prężnego środowiska gnostyckiego ${ }^{36}$. Najważniejszą z postaci był zapewne Adda wspominany nie tylko przez św. Augustyna ${ }^{37}$ jako Adeimantos/Adimantus, ale i przez chińskie źródła jako A-to. Dotarł on do Aleksandrii, powoływał electi i auditores, zakładał klasztory i był autorem szeregu pism krzewiących manicheizm ${ }^{38}$.

Manichejczycy konkurują z powoli rozwijającym się chrześcijaństwem doliny Nilu i tworzą podstawy instytucji klasztornych przejętych później przez Pachomiusza, uchodzącego za ojca chrześcijańskiego monastycyzmu. Jak sugerował już Karl Heussi w swojej klasycznej historii powstania monastycyzmu ${ }^{39}$, byli oni nie tylko prekursorami tej formy życia, ale ugruntowali również ideę anachorezy reprezentowanej później przez św. Antoniego ${ }^{40}$.

Do jakiego stopnia wpłynęły na to prześladowania Dioklecjańskie (290-305), pozostaje wciąż przedmiotem dyskusji, niemniej osiedlanie się w oazach może być tego wyrazem. Guy Stroumsa sugeruje (zob. przyp. 41), nawiązując do Waltera Bruna Henninga, wczesne powstawanie „manistanów", czyli domów klasztornych, których egzystencję w ostatnich deceniach III w. potwierdziły wykopaliska Anthony'ego J. Millsa w Kellis i publikacje Iana Gardnera, chyba jednego z najlepszych znawców nowoodkrytych tekstów i ich „osadzenia w życiu” (Sitz im Leben) późnego antyku".

tenże, Erwägungen zur Herkunft des Judasevangeliums, ZNW 101 (2010) 93-118. Niestety polski tekst (W. Myszor, Ewangelia Judasza, w: Apokryfy Nowego Testamentu, II: Ewangelie apokryficzne, cz. 1: Apostołowie. Bartłomiej, Filip, Jakub Mniejszy, Jakub Większy, Judasz, Maciej, Mateusz, Szymon i Juda Tadeusz, Ewangeliści, Uczniowie Pańscy, red. M. Starowieyski, Kraków 2007, 887-906) jest bezkrytyczny i wymaga w następnych wydaniach koniecznych rewizji. Por. również K. Pilarczyk, „Ewangelia Judasza” a pierwotne chrześcijaństwo i gnostycyzm. Rekonesans badawczy, w: Chrześcijaństwo antyczne, red. J. Drabina, Kraków 2006, 23-24.

${ }^{34}$ Por. J.A.L. Vergote, Der Manichäismus in Ägypten, w: Der Manichäismus, hrsg. G. Widengren, Darmstadt 1977, 385-399; S.N.C. Lieu, Manichaeism in the Later Roman Empire and Medieval China, Wissenschaftliche Untersuchungen zum Neuen Testament 63, Tübingen 1992², 90.

${ }^{35}$ Por. J.P. Asmussen - A. Böhlig, Die Gnosis III. Der Manichäismus, Zürich - München 1980, 130.

${ }^{36}$ Por. C.W. Griggs, Early Egyptian Christianity from its origin to 451 C.E., Leiden 1991, 95.

${ }^{37}$ Por. Augustinus, Contra adversarium legis et prophetarum II 42.

${ }^{38}$ Por. Griggs, Early Egyptian Christianity, s. 93 i 299.

${ }^{39}$ Por. K. Heussi, Der Ursprung des Mönchtums, Tübingen 1936, 290; S. Rubenson Ch. Hornung, Mönchtum, RACh XXIV 1009-1064.

${ }^{40}$ Por. noty 42, 44 i 48. Obszerniej na ten temat z uwzględnieniem bogatej literatury przedmiotu w mojej poszerzonej rozprawie prezentowanej na Uniwersytecie w Tybindze w 2011 r.: Anfänge und Verbreitung des Mönchtums in Nubien [Eine Skizze].

${ }^{41}$ Por. Gardner, , He has gone to the monastery...”, s. 247-57. 
Od czasu próby syntetycznego spojrzenia Ludwiga Koenena ${ }^{42}$, podzielanego przez innych badaczy, oraz ich spostrzeżeń dotyczących manichejskiego monastycyzmu, narosła bogata literatura przedmiotu, jak też pojawiły się nowe manichejskie źródła (szczególnie te z Kellis), korespondujące m.in. z gnostyczną literaturą kultur basenu Morza Czerwonego (używam tutaj tego pojęcia $\mathrm{w}$ analogicznym sensie jak przyjęto to $\mathrm{w}$ odniesieniu do kultur basenu Morza Śródziemnego ${ }^{43}$. Powszechnie wychodzi się z założenia, iż manichejczycy dotarli do Egiptu nie tylko przez Aleksandrię ${ }^{44}$, ale i ze Wschodu, z Palestyny i Arabii, przez porty czerwonomorskie (m.in. Berenikę).

Dlatego też nie dziwi fakt, iż Lycopolis (obecnie Assiut) - a tym samym nawet i cały środkowy Egipt oraz jego oazy - stały się centrum działalności misyjnej manichejczyków ${ }^{45}$. Przy tym wszystkim zastanawia fakt, iż region ten nie tylko w starożytności, ale i dzisiaj jest ciągle ostoją Koptów, co wskazuje na długowieczne oddziaływanie swoistego fenomenu spiritus loci w dziejach tej starej kultury. Czy można tu jednak mówić o krypto-manicheizmie, czyli jak to zwie Stroumsa „marranizmie”, musimy pozostawić dalszej dyskusji ${ }^{46}$.

Stwierdzenie Jana Heldermana, że „die manichäische Missionare von Südosten her nach Ägypten kamen, d.h. nach Oberägypten”47 („manichejscy misjonarze dotarli do Egiptu z południowego-wschodu, tzn. osiagnęli [najpierw] górny Egipt"), jak i inne obserwacje dotyczące historii monastycyzmu w dolinie Nilu ${ }^{48}$, tj. również w Nubii i dzisiejszej Etiopii, pozwalają przypuszczać, iż manichejczycy prowadzili nie tylko intensywną działalność misyjna, ale również zakładali w całej północno-wschodniej Afryce klasztory, będące w wielu przypadkach podstawą późniejszej jednoznacznie chrześcijańskiej monastyzacji rozprzestrzeniającej się z Egiptu dalej na północ i zachód.

${ }^{42}$ Por. L. Koenen, Manichäische Mission und Klöster in Ägypten, w: Das römisch-byzantinische Ägypten. Akten des Internationalen Symposiums 26.-30. September 1978 in Trier, hrsg. G. Grimm, Aegyptiaca Treverensia 2, Mainz 1983, 93-108.

${ }^{43}$ Por. P.O. Scholz, Orbis aethiopicus - Kulturraum um das Rote Meer, w: Orbis Aethiopicus: Studia in honorem Stanislaus Chojnacki natali septuagesimo quinto dicata, septuagesimo septimo oblata, hrsg. P.O. Scholz, Albstadt 1992, XXIII-XXXI; T. Power, The Red Sea from Byzantium to the Caliphate AD 500-1000, Cairo 2012.

${ }^{44}$ Por. G. Stroumsa, The Manichaean Challenge to Egyptian Christianity, w: The roots of Egyptian Christianity, ed. B.A. Pearson - J.E. Goehring, Philadelphia 1986, 307-319.

${ }^{45}$ Por. Alexander Lycopolitanus, Contra Manichaei opiniones disputatio, ed. A. Bünkmann: Alexandri Lycopolitani contra Manichaei opiniones disputatio, Leipzig 1895.

${ }^{46}$ Por. G. Stroumsa, Monachisme et Marranisme chez les Manichéens d'Egypte, „Numen” 28 (1982) 184-201.

${ }^{47} \mathrm{~J}$. Helderman, Manichäische Züge im Thomasevangelium, w: Ägypten und Nubien in spätantiker und christlicher Zeit. Akten des 6. Internationalen Koptologenkongresses (Münster, 20.-26. Juli 1996), II, hrsg. S. Emmel - M. Krause - S.G. Richter - S. Schaten,, Wiesbaden 1999, 483.

${ }^{48}$ Por. F. Wisse, Gnosticism and Early Monasticism in Egypt, w: Gnosis: Festschrift für Hans Jonas, hrsg. B. Aland, Göttingen 1978, 431-440. 
Konsekwencje, jakie wynikają z tych okoliczności, są daleko idące i dotyczą m.in. chrystianizacji Nubii, która przy uwzględnieniu manichejskiej penetracji musiała mieć miejsce już w okresie przedjustyniańskim. Dostrzeżenie tego faktu pozwoli być może niektórym badaczom, tkwiącym ciągle w błędnym przekonaniu, iż Justyniańska misja była pierwszym krokiem w chrystianizacji Nubii, na konieczną weryfikację dotychczasowych stanowisk niezmiernie utrudniających właściwą ocenę historii chrześcijańskiej Nubii ${ }^{49}$. Dlatego też nie należy wykluczać, iż niektóre klasyczne teksty, jak np. popularne w Egipcie i w Nubii Vita Onophrii ${ }^{50}$, które wymieniają „owłosionego mężczyznę”, mając na myśli anachoretów/pneumatyków, przekonanych o możliwości „rajskiego życia" poza gnuśną cywilizacją. Takie wyobrażenia zdają się sięgać w swych początkach do źródeł manichejskich z III-IV w. (zob. niżej), które z kolei - jak powszechnie wiadomo - partycypują w wielu różnorodnych tradycjach literackich: irańskich, żydowskich, buddyjskich, chrześcijańskich, wreszcie i innych gnostyckich, przyjmując do celów misyjnych regionalne języki i pisma bez jakichkolwiek predyspozycji dla jednego języka sakralnego. Mani głosił:

„Moja nadzieja pójdzie na Zachód i pójdzie również na Wschód. I będzie słychać głos jej obwieszczania we wszystkich językach, i będzie ją obwieszczać we wszystkich miastach. Moja religia przewyższa pod tym względem wszystkie wcześniejsze religie, albowiem wcześniejsze religie założono w poszczególnych miejscach i poszczególnych miastach. Moja religia wyjdzie we wszystkich miastach, a jej orędzie dotrze do każdego kraju"51.

Popularna postać ascety zachowała się w źródłach ikonograficznych, z których jedno z najstarszych pochodzi z Faras (Pachoras), Onophrios (il. 2) ${ }^{52}$, kolejne wzbogacają zaś repertuar ikonografii hagiograficznej, o której swego

${ }^{49}$ Niniejszą problematykę poruszyłem ponownie w: Noch einmal zum frühen Auftreten der Christen in Nubien. Einige Randbemerkungen zum „Bericht” des Johannes von Ephesos, OC 94 (2010) 124-147, uwzględniając dotychczasową literaturę przedmiotu. Por. również moją recenzję: Bogdan Żurawski, St. Raphael Church I. at Banganarti mid-sixth to mid-eleventh century. An introduction to the site and the epoch (African reports 10/2012, Monograph Series 2/ zugleich Banganarti 1/NUBIA IV), Gdańsk 2012, SS. 437, mit zahlreichen Abb.n [pb. Format 29,5 x 21,00 cm], OC 96 (2012) 296-297.

${ }^{50}$ Por. R. Reitzenstein, Historia monachorum und Historia Lausiaca. Eine Studie zur Geschichte des Mönchtums und der frühchristlichen Begriffe Gnostiker und Pneumatiker, Göttingen 1916, 180-184; Vita Onophrii zostały spisana przez Pafnucego (BHG 1378); por. też Z. Szczudłowska W. Godlewski, Koptyjska legenda o świętym Onufrym, „Euhemer” 3 (1971) 23.

${ }^{51}$ Kephalaia, ed. Polotsky - Böhlig, s. 16, tłum. własne z niemieckiego: Rudolph, Die Gnosis, s. 330; por. też tłumaczenie polskie G. Sowińskiego: Rudolph, Gnoza, s. 290. Zob. P.O. Scholz, Die Sehnsucht nach tausendundeiner Nacht. Begegnung von Orient und Okzident, Stuttgart 2002, 47-50. W tym kontekście zwraca na siebie uwagę fakt, iż sam Mani nie uważał się za gnostyka i dlatego dyskusja na ten temat podjęta ostatnio przez Petera Nagela (Über das Verhältnis von Gnosis und Manichäismus, oder: Wie gnostisch ist die Gnosis des Mani? nabiera szczególnego znaczenia.

${ }^{52}$ Por. Galeria Faras. Przewodnik, red. B. Mierzejewska, Warszawa 2014, 118-119 (il. 22). 
czasu pisała Anna Sienkiewicz-Bartoszuk ${ }^{53}$. Święty ten pojawia się również w tekstach manichejskich, które w świetle aktualnych poszukiwań zdają się być źródłem licznych opowiadań rozprzestrzeniających się w Oriencie, o czym świadczą różnorodne wersje językowe tego ciekawego literackiego motywu ,podróży do owłosionego anachorety” ${ }^{54}$.

Cornelia Eva Römer poświęciła m.in. temu motywowi swój szeroko rozbudowany komentarz do znanego greckiego kolońskiego kodeksu manichejskiego (CMC). Jeden jego fragment - w przekładzie polskim - musi tutaj wystarczyć:

„On [tzn. mój bliźniak] wzniósł mnie na najwyższą górę [w tym swoistym niemalże nieziemskim, rajskim krajobrazie] i tam obaczyłem człowieka pokrytego na całym ciele łokieć długimi i gęstymi, kręcącymi się włosami. [...] [Mani przemówił do niego] Jak doszło do tego owłosienia twego ciała, co cię tak wyróżnia od innych ludzi i dlaczego tutaj przybyłeś? [on odrzekł] W moim ogrodzie wszedłem raz na drzewo, którego owoce były najprzedniejsze/najlepsze i od tego momentu moje ciało pokryło się owymi włosami"55.

Jest niestety niemożliwe pozwolić sobie w tym krótkim artykule na dłuższe porównawcze zestawienie fragmentów różnorodnych źródeł, oscylujących pomiędzy kanoniczną literaturą biblijną, apokryfami, tekstami z apoftegmatów i kodeksem Maniego, dlatego zainteresowanych można tylko skierować do cytowanej tutaj literatury przedmiotu.

Na zakończenie pragnę zwrócić uwagę na jeszcze jedno zjawisko związane $\mathrm{z}$ manicheizmem, a mające poważne znaczenie dla oceny południowo-wschodniej doliny Nilu jako regionu intensywnej penetracji i wpływów tego gnostyzującego kierunku religijnego. Otóż w Kephalaii jesteśmy konfrontowani ze szczególnym podkreśleniem znaczenia królestwa aksumskiego (etiopskiego) jako jednego z czterech dominujących państw w okresie tzw. Achsenzeit. Było bowiem zleceniem misyjnym Maniego dla jego adeptów i zwolenników, aby i to terytorium - czyli południe - objąć jego nauka, jak to wykazali w swoich przyczynkach François de Blois i Michael Tardieu ${ }^{56}$. Podobnie jak w Imperium Romanum (zachód), w Persji (na wschód) i oczywiście w Chinach (północ), także wśród Etiopczyków (południe) $)^{57}$ ma być gło-

${ }^{53}$ Por. A. Sienkiewicz-Bartoszuk, Przedstawienia św. Onufrego na ziemiach polskich, „Series Byzantina" 2 (2004) 155-166.

${ }^{54}$ Por. C.E. Römer, Manis frühe Missionsreisen nach der Kölner Manibiographie, Opladen 1994, 41-71.

${ }^{55}$ CMC 126nn, cyt. za Koenen - Römer, Mani. Auf den Spuren einer verschollenen Religion, s. 97, tłum. własne z niemieckiego. W nawiasach kwadratowych znajdują się moje wyjaśnienia wynikające $\mathrm{z}$ tekstu. Por. ciągle jeszcze istotne uwagi dotyczące „owłosionego człowieka” (ascety) w: Reitzenstein, Historia monachorum und Historia Lausiaca, s. 172-184, nota. 45.

${ }^{56}$ F. de Blois, The ,four great kingdoms" in the Manichaean Kephalaia, w: Orbis Aethiopicus, s. 221-230; M. Tardieu, L'enigme du quatrième empire, w: Orbis Aethiopicus, s. 259-266.

${ }^{57}$ Czyli zgodnie z ówczesną grecką nomenklaturą na południe od Egiptu (por. A. Dihle, 
szona ta uniwersalna nauka zbawienia. Dlatego też nie dziwi fakt znajdowania rozrzuconych na cztery strony świata literackich i ikonicznych potwierdzeń manichejskiej działalności, której ostatnie ślady zachowały się jeszcze w XVI/ XVII w. u Uigurów ${ }^{58}$. Zasługujące na uwagę malowidła ścienne z VIII w. przedstawiające owych przysłowiowych czterech władców świata w jednym z niemalże zapomnianych omajjadzkich zameczków w Qusair Amra, odkrył w 1900 r. Alois Musil (1868-1944), a znaczenie ich podkreślił identyfikując postaci władców z Caesarem (władcą Bizancjum), Roderykiem (ostatnim królem Gotów przed inwazją islamską), Kisra (sasanidzkim „królem królów”), Negusem (władcą Etiopii), zmarły niedawno znawca przedmiotu Oleg Grabar (1929-2011) $)^{59}$, syn znanego badacza wczesnochrześcijańskiej ikoniczności André Grabara (1896-1990).

Można by jeszcze wiele mówić o manichejczykach i ich wpływach, jedno wszak wydaje się pewne, iż neomanichejskie ruchy bogomiłów, katarów, adamitów i innych tajemnych sekt gnostyckich działających w Azji i Europie pomiędzy wyprawami krzyżowymi a reformacją ${ }^{60}$, pozostawiły wpływy, które zaimplikowały nawet przestrzeń wizualną średniowiecza, jak i początków czasów nowożytnych, np. Hieronima Boscha (1450?-1516) ${ }^{61}$. Ta kontynuacja quasi zapomnianej religii, zawartej w strukturach ikoniczności zrodzonej w końcu III w., zdaje się żyć dalej w mistycznych wyobrażeniach przezwyciężenia zła, wizualizowanego w piekielnych ciemnościach, nad którymi zwycięstwo odnosi niebiańskie, nieskończone światło absolutnego dobra.

Tym samym badania nad manicheizmem można uznać za paradygmatyczne nie tylko dla problematyki ,pogranicza chrześcijaństwa”, ale dla całego wczesnego chrześcijaństwa konfrontowanego z różnorakimi gnostyzującymi kierunkami, ostro prześladowanymi przez cesarskie edykty ${ }^{62}$, które m.in. spychały

Umstrittene Daten. Untersuchungen zum Auftreten der Griechen am Roten Meer, Köln 1965, 65nn); Lieu, Manichaeism in the Later Roman Empire, s. 234-237 i 241-242.

${ }^{58}$ Por. Rudolph, Gnoza, s. 333.

${ }^{59}$ Por. A. Musil, Arabia Petraea, I, Wien 1907 (repr. 1989), 219-233; O. Grabar, Die Entstehung der islamischen Kunst, Köln 1977, 53 i fig. 3 (por. register Qusair Amra). Niewykluczone, iż identyfikowany przez Grabara „Negus” jest królem nubijskim. Szerzej na ten temat por. P.O. Scholz, Mani und die christliche Ikonizität - eine Skizze, w: Orientalia Christiana. Festschrift für Hubert Kaufhold zum 70. Geburtstag, hrsg. P. Bruns - H.O. Luthe, Wiesbaden 2013, 471nn.

${ }^{60}$ Por. S. Runciman, The Medieval Manichee. A Study of the Christian Dualist Heresy, Cambridge 1947 (polskie wydanie - Manicheizm średniowieczny, thum. J. Prokopiuk - B. Zborski, Gdańsk 1996); literatura uzupełniająca - por. niemieckie wydanie (Häresie und Christentum: der mittelalterliche Manichäismus, München 1988, 328-329).

${ }^{61}$ Por. L. Harris, Hieronymus Bosch und die geheime Bildwelt der Katharer, Stuttgart 1996; por. także P.O. Scholz, Kontinuierliche ikonische Narrativität über das Paradiesische am Beispiel der Wiener Genesis und des Weltbildes des „, Gnostikers” Hieronymus Bosch, w: Sehnsucht nach dem Paradies, hrsg. J. Tubach - A. Drost-Abgarjan - S. Vashalomidze, Wiesbaden 2010, 117-157.

${ }^{62}$ Por. H.-G. Beck, Actus fidei. Wege zum Autodafé, Sitzungberichte der Bayerischen Akademie der Wissenschaften. Philosophisch-Historische Klasse 3, München 1987, 16-21. 
manichejczyków coraz bardziej na Wschód. Jednocześnie wczesne pojawienie się manichejskiej, ideowo motywowanej ikoniczności (Ardahang) stanęło u kolebki rodzącej się wówczas wizualizacji kanonicznych treści również młodej w tym czasie nauki i życia Chrystusa. Rozprzestrzenianie się chrześcijaństwa, ale i jego herezji, zostało dopiero wstrzymane i zdominowane przez ekspansje islamu (VII/VIII w.), aby wreszcie ulec, szczególnie w Azji, wzdłuż tzw. ,jedwabnych szlaków”, niemalże totalnej eliminacji. „Apostoł Jezusa Chrystusa” - jak określał się sam Mani - znalazł jednak akceptację w średniowiecznym królestwie Uigurów (762-840), które uznało manicheizm za religię państwową, trwającą na jego terenie w swych rudymentach aż do XVI/XVII w. Pozostawiła ona świetne przykłady synkretyzującej ikonografii w służbie religii.

Rozmiary tego artykułu pozwoliły tylko na zasygnalizowanie bardzo złożonej problematyki chrystianizacji starożytnego świata i narodzenia się jej ikoniczności ${ }^{63}$ ze szczególnym uwzględnieniem południowych szlaków tzw. „drogi jedwabnej” ${ }^{4}$, wchłoniętej przez trakty handlowe obejmujące również basen Morza Czerwonego ${ }^{65}$, będący zarodkiem nowych ruchów religijnych, które wstrząsnęły światem i które po dzień dzisiejszy wyciskają swoje znamienne piętno „ostatniej pieczęci proroctwa”, za którą uchodzi nie tylko Muhammad, ale za jaką uważał się już Mani ${ }^{66}$ !

\section{MANICHAEAN MISSIONARY ACTIVITY AND MONASTICISM IN THE NILE VALLEY AND THEIR INFLUENCE ON LOCAL CHRISTIANITY ON THE VERGE OF THE $3^{\mathrm{RD}}$ AND $4{ }^{\mathrm{TH}}$ CENTURIES}

\section{(Summary)}

Since the discovery of the substantial corpus of Manichaean writings, especially the Kephalaia (editio princeps Polotsky-Böhlig, 1934-1940), the Cologne Mani Codex (= CMC), and the hitherto incompletely published library from Dachla (Ian Gardner, 2000), there can be no doubt as to the activities of the missionaries of the great Persian gnostic Mani in the Southern Nile Valley and Red Sea regions. This fact not only confirms the views of J. Helderman "that the Manichaean missionaries entered Egypt from the South-East, i.e. initially to Upper

\footnotetext{
${ }^{63}$ Szerzej na ten temat w: Scholz, Mani und die christliche Ikonizität, s. 459-475, il. 660-676.

${ }^{64}$ Por. J. Tubach, Die nestorianische Kirche in China, „Nubica et Aethiopica” 4/5 (1999) 61-193 z obszerną bibliografią dotycząca, „szlaków jedwabnych” i ich znaczenia dla rozprzestrzeniającego się chrześcijaństwa. Zob. Ch. Baumer, Frühes Christentum zwischen Euphrat und Jangtse. Eine Zeitreise etlang der Seidenstraße zur Kirche des Ostens, Stuttgart 2005.

${ }^{65}$ Por. A. Dihle, Indien, RACh XVIII 1-56; P.O. Scholz, Aithiopen und der Osten: Bemerkungen $z u$ den Kontakten entlang der sogenannten südlichen „Seidenstrasse”, unter besonderer Berücksichtigung der altorientalischen und iranischen Quellen, „Nubica“ 1/2 (1990) 295-310; Baumer, Frühes Christentum, s. 141-172.

${ }^{66}$ Por. C. Colpe, Das Siegel des Propheten, Berlin 1989, 134nn i $231 \mathrm{nn}$.
} 
Egypt” ('Manichäische Züge im Thomasevangelium', 483f., note 42), but also the historical observations concerning the origins and development of monasticism. The latter was not without Manichaean influence, not merely in Egypt, but also in Nubia and Ethiopia.

A mosaic, seemingly depicting Mani (from the collection of Elie Borowski), testifies to the pictorial needs of the Manichaeans as do the mural paintings from Pachoras/Faras depicting the likeness of Onophrios. These demonstrate the popularity of the crinite ascetic", a figure also found in the CMC.

It is imperative to recall the decisive importance of the southern kingdoms along the Red Sea during the Axial Age (Karl Jaspers), in order to kindle historical awareness in Europe of this currently overlooked region on the eve of its islamicisation - something which for decades I have noted the importance of in numerous publications (cf. foot-note 40). Here, local Christianity (viewed anachronistically) was marked by a heretical-gnostic diversity from the very beginning, which in turn weakened the spread of Christian teaching in the region. Islam was initially seen here by some as a Christian heresy (as pointed out by A. v. Harnack) and which even became accepted (e.g. in Ethiopia or Nubia, as noted by H. Jansen, Muhammed [German ed.: Münich 2008], 141). Thus, the local doctrinal pluriformity of Christianity during the jähiliyya prepared the way for the later Islamic expansion.

Manichaeism belongs unequivocally to the "periphery cultures of the Christian world" (Pogranicza chrześcijaństwa) as well as constituting a part of expanding Christianity in the Late Antique world. Manichaeism still holds many secrets, but at the same time their answers, as illustrated by this article. Hence, the gnostic element of Early Christianity is worthy of continued intensive study, something which unfortunately in Poland is still quite inadequate.

Translated by Robert Kerr

Key words: Mani, gnosis, early Christian mission, Egypt, patristics.

Słowa kluczowe: Mani, gnoza, misja wczesnochrześcijańska, Egipt, patrystyka.

\section{BIBLIOGRAFIA}

\section{Źródła}

Alexander Lycopolitanus, Contra Manichaei opiniones disputatio, ed. A. Bünkmann: Alexandri Lycopolitani contra Manichaei opiniones disputatio, Leipzig 1895.

Augustinus, Enarrationes in Psalmos, PL 36-37.

Kephalaia, ed. H.J. Polotsky - A. Böhlig, Stuttgart 1940.

The Nag Hammadi library, ed. J.M. Robinson, Leiden 1984.

Opracowania

Asmussen J.P. - BöHLıg A., Die Gnosis III. Der Manichäismus, Zürich - München 1980. BANG-KAUP W., Manichäische Erzähler, Berlin 1931. 
BAumer Ch., Frühes Christentum zwischen Euphrat und Jangtse. Eine Zeitreise etlang der Seidenstraße zur Kirche des Ostens, Stuttgart 2005.

BAUR F.Ch., Das manichäische Religionssystem, Tübingen 1831.

Beck H.-G., Actus fidei. Wege zum Autodafé, Sitzungberichte der Bayerischen Akademie der Wissenschaften. Philosophisch-Historische Klasse 3, München 1987.

BeDuhn J.D. - Mirecki P., Frontiers of faith. The Christian encounter with Manichaeism in the Acts of Archelaus, Leiden 2007.

Blois F. de, The „four great kingdoms” in the Manichaean Kephalaia, w: Orbis Aethiopicus: Studia in honorem Stanislaus Chojnacki natali septuagesimo quinto dicata, septuagesimo septimo oblata, hrsg. P.O. Scholz, Albstadt 1992, 221-230.

BöHLIG A. - VAN OORT J., Manichaeism, w: Dictionary of Gnosis \& Western Esotericism, ed. W.J. Hanegraaff, Leiden 2006, 756-765.

BöHlig A., Mani, Manichäismus, RGG4 V 732-741.

BöHLIG A., Manichäismus, TRE XXII 25-45.

Carl-Schmidt-Kolloquium an der Martin-Luther-Universität 1988, hrsg. P. Nagel, Halle an der Saale 1990.

Colpe C., Das Siegel des Propheten, Berlin 1989.

Dihle A., Indien, RACh XVIII 1-56.

Dinle A., Umstrittene Daten. Untersuchungen zum Auftreten der Griechen am Roten Meer, Köln 1965.

Drecoll V. H. - Kudella M., Augustinus und der Manichäismus, Tübingen 2012.

Feldmann E., Christus-Frömmigkeit der Mani-Jünger. Der suchende Student Augustinus in ihrem „Netz”?, w: Pietas, Festschift Bernhard Kötting, hrsg. E. Dassman K.S. Frank, Münster (Westfalen) 1980, 198-216.

GAISER K., Das Philosophenmosaik in Neapel. Eine Darstellung der platonischen Akademie, Heidelberg 1980.

Galeria Faras. Przewodnik, red. B. Mierzejewska, Warszawa 2014.

Grabar O., Die Entstehung der islamischen Kunst, Köln 1977.

Griggs C.W., Early Egyptian Christianity from its origin to 451 C.E., Leiden 1991.

Gulácsi Z., Mediaeval Manichaean book art, Leiden - Boston 2005.

Harris L., Hieronymus Bosch und die geheime Bildwelt der Katharer, Stuttgart 1996.

Heinrichs A. - Koenen L., Ein griechische Mani-Codex, Bonn 1970.

Helderman J., Manichäische Züge im Thomasevangelium, w: Ägypten und Nubien in spätantiker und christlicher Zeit, II, hrsg. S. Emmel, Wiesbaden 1999, 483-494.

Heussi K., Der Ursprung des Mönchtums, Tübingen 1936.

Hutter M., Die Bedeutung des syrischen Christentums für die gnostische Religion Manis, w: Religionsgeschichte Syriens, hrsg. P.W. Haider - M. Hutter - S. Kreuzer, Stuttgart 1996, 261-272.

HutTer M., Manichäismus, RACh XXIV 6-48.

JASPERS K., Vom Ursprung und Ziel der Geschichte, Frankfurt am Main 1955.

Kleines Lexikon des Christlichen Orients, hrsg. H. Kaufhold, Wiesbaden 2007.

KuIJn A.F.J., Edessa, die Stadt des Apostels Thomas, Neukirchen 1965.

Kuimkeit H.-J., Gnosis and the Silk Road, San Francisco 1993.

KLImKeIT H.-J., Mani, Manichäismus, LThK³ VI 1265-1269. 
KLimkeIT H.-J., Manichaean art and calligraphy, Iconography of Religions 20, Leiden 1982.

Koenen L., Manichäische Mission und Klöster in Ägypten, w: Das römisch-byzantinische Ägypten. Akten des Internationalen Symposiums 26.-30. September 1978 in Trier, hrsg. G. Grimm, Aegyptiaca Treverensia 2, Mainz 1983, 93-108.

Lecoq A. von, Auf Hellas Spuren in Ostturkistan, Berlin 1926.

LeCoQ A. von, Die buddhistische Spätantike im Mittelasien, I-VII, Berlin 1922-1933.

Lieu S., Manichaeism in the Later Roman Empire and Medieval China, Wissenschaftliche Untersuchungen zum Neuen Testament 63, Tübingen $1992^{2}$.

Lieu S., Manichaeism, w: Late Antiquity: A Guide to the Postclassical World, ed. G.W. Bowersock - P. Brown - O. Grabar, Harvard 1999, 555-556.

ŁukAszewicz A., Świat papirusów, Warszawa 2001.

Mani. Auf den Spuren einer verschollenen Religion, hrsg. L. Koenen - C. Römer, Freiburg im Breisgau 1993.

MARKSCHIES Ch., Gnostische und andere Bilderbücher in der Antike, ZACh 9 (2005) $100-121$.

Mélèze Modrzejewski J., Les juifs d'Égypte de Ramsès II à Hadrien, Paris 1992.

Musil A., Arabia Petraea, Wien 1907 (repr. 1989).

Myszor W., Znaczenie tekstów z Nag Hammadi w badaniach pierwotnego chrześcijaństwa, „Acta Universitatis Nicolai Copernici. Nauki Humanistyczno-Społeczne. Historia" 27 (1992) 159-164.

NAGEl P., Das Evangelium des Judas - zwei Jahre später, ZNW 100 (2009) 101-138.

NAGEL P., Erwägungen zur Herkunft des Judasevangeliums, ZNW 101 (2010) 93-118.

Nagel P., Über das Verhältnis von Gnosis und Manichäismus, oder: wie gnostisch ist die Gnosis von Mani?, w: Vom „,Troglodytenland” ins Reich der Scheherazade. Archäologie, Kunst und Religion zwischen Okzident und Orient, hrsg. M. Długosz, Berlin 2014, 121-140.

Nagel P., ZЛГРАФЕIN und das „Bild” des Mani in den koptisch-manichäischen Texten, w: Eikon und Logos. Beiträge zur Erforschung byzantinischer Kulturtraditionen, Konrad Onasch zur Vollendung des 65. Lebensjahres, hrsg. H. Goltz, Halle an der Saale 1981, 199-238.

OоRT J. van, Augustine and Manichaeism in the Latin West, Leiden - Boston 2001.

Pestman P.W., The new Papyrological Primer, Leiden 1940.

Pigulewska N.W., Kultura syryjska we wczesnym średniowieczu, Warszawa 1989.

PILARCZyK K., „Ewangelia Judasza” a pierwotne chrześcijaństwo i gnostycyzm. Rekonesans badawczy, w: Chrześcijaństwo antyczne, red. J. Drabina, Kraków 2006, 23-24.

Power T., The Red Sea from Byzantium to the Caliphate AD 500-1000, Cairo 2012.

Pratscher W., Geschichte des syrischen Christentums bis zum Beginn des 7. Jahrhunderts, w: Religionsgeschichte Syriens, hrsg. P.W. Haider - M. Hutter - S. Kreuzer, Stuttgart 1996, 273-284.

ReITZENSTEIN R., Historia monachorum und Historia Lausiaca. Eine Studie zur Geschichte des Mönchtums und der frühchristlichen Begriffe Gnostiker und Pneumatiker, Göttingen 1916.

RöMER C.E., Manis frühe Missionsreisen nach der Kölner Manibiographie, Opladen 1994. Rose E., Die manichäische Christologie, Wiesbaden 1979. 
Rudolph K., Gnoza. Istota i historia późnoantycznej formacji religijnej, thum. G. Sowiński, Kraków 1995.

RumscheId J., Familienbilder im Haus der Ewigkeit. Zu Grabmosaiken aus Edessa, w: Edessa in hellenistisch-römischer Zeit, hrsg. L. Greisiger - C. Rammelt - J. Tubach, Beiruter Texte und Studien 116, Beirut 2009, 255-265.

Runciman S., Manicheizm średniowieczny, tłum. J. Prokopiuk - B. Zborski, Gdańsk 1996.

Scholz P.O., Aithiopen und der Osten: Bemerkungen zu den Kontakten entlang der sogenannten südlichen ,, Seidenstrasse”, unter besonderer Berücksichtigung der altorientalischen und iranischen Quellen, „Nubica” 1/2 (1990) 295-310.

Scholz P.O., Die Sehnsucht nach tausendundeiner Nacht. Begegnung von Orient und Okzident, Stuttgart 2002.

Scholz P.O., Gnostische Elemente in der nubischen Wandmalereien: Das Christusbild, „Nubica” 1-2 (1987/1988) 565-584.

Scholz P.O., Kontinuierliche ikonische Narrativität über das Paradiesische am Beispiel der Wiener Genesis und des Weltbildes des ,, Gnostikers” Hieronymus Bosch, w: Sehnsucht nach dem Paradies, hrsg. J. Tubach - A. Drost-Abgarjan - S. Vashalomidze, Wiesbaden 2010, 117-157.

Scholz P.O., Mani und die christliche Ikonizität - eine Skizze, w: Orientalia Christiana. Festschrift für Hubert Kaufhold zum 70. Geburtstag, hrsg. P. Bruns - H.O. Luthe, Wiesbaden 2013, 459-476.

Scholz P.O., Noch einmal zum frühen Auftreten der Christen in Nubien. Einige Randbemerkungen zum „Bericht” des Johannes von Ephesos, OC 94 (2010) 124-147.

Scholz P.O., Orbis aethiopicus - Kulturraum um das Rote Meer, w: Orbis Aethiopicus: Studia in honorem Stanislaus Chojnacki natali septuagesimo quinto dicata, septuagesimo septimo oblata, hrsg. P.O. Scholz, Albstadt 1992, XXIII-XXXI.

Schubart W., Einführung in die Papyruskunde, Berlin 1918.

Sienkiewicz-Bartoszuk A., Przedstawienia św. Onufrego na ziemiach polskich, „Series Byzantina" 2 (2004) 155-166.

STACHURA M., Heretycy, schizmatycy i manichejczycy wobec cesarstwa rzymskiego (lata 324-428, wschodnia część Imperium), Kraków 2000.

Stroumsa G., Monachisme et Marranisme chez les Manicheens d'Egypte, „Numen” 28 (1982) 184-201.

Stroumsa, G., The Manichaean Challenge to Egyptian Christianity, w: The roots of Egyptian Christianity, ed. B.A. Pearson - J.E. Goehring, Philadelphia 1986, 307-319.

Studia Manichaica: Proceedings of the IV ${ }^{\text {th }}$ International Conference of Manichaean Studies, Berlin 1997, ed. R.E. Emmerick - W. Sundermann - P. Zieme, Berlin 2000.

Sundermann W., Was the „Ardahang” Mani's picture book?, „Manichaean Studies” 5 (2005) 373-384.

SzczudŁowska Z. - Godlewski W., Koptyjska legenda o świętym Onufrym, „Euhemer” 3 (1971) 23-26.

ŚwIDEREK A., Kiedy piaski egipskie przemówity po grecku, Warszawa 1950.

TARDIEU M., L'enigme du quatrième empire, w: Orbis Aethiopicus: Studia in honorem Stanislaus Chojnacki natali septuagesimo quinto dicata, septuagesimo septimo oblata, hrsg. P.O. Scholz, Albstadt 1992, 259-266.

TARDIEU M., Manichéisme, Paris 1981. 
Tubach J., Die nestorianische Kirche in China, „Nubica et Aethiopica” 4/5 (1999) 61-193. Vergote J.A.L., Der Manichäismus in Ägypten, w: Der Manichäismus, hrsg. G. Widengren, Darmstadt 1977, 385-399.

Widengren G., Mani und Manichäismus, Stuttgart 1961.

Wisse F., Gnosticism and Early Monasticism in Egypt, w: Gnosis: Festschrift für Hans Jonas, hrsg. B. Aland, Göttingen 1978, 431-440.

Yaldiz M., Archäologie und Kunstgeschichte Chinesisch-Zentralasiens (Xinjiang), Leiden 1987.

\section{ANEKS}

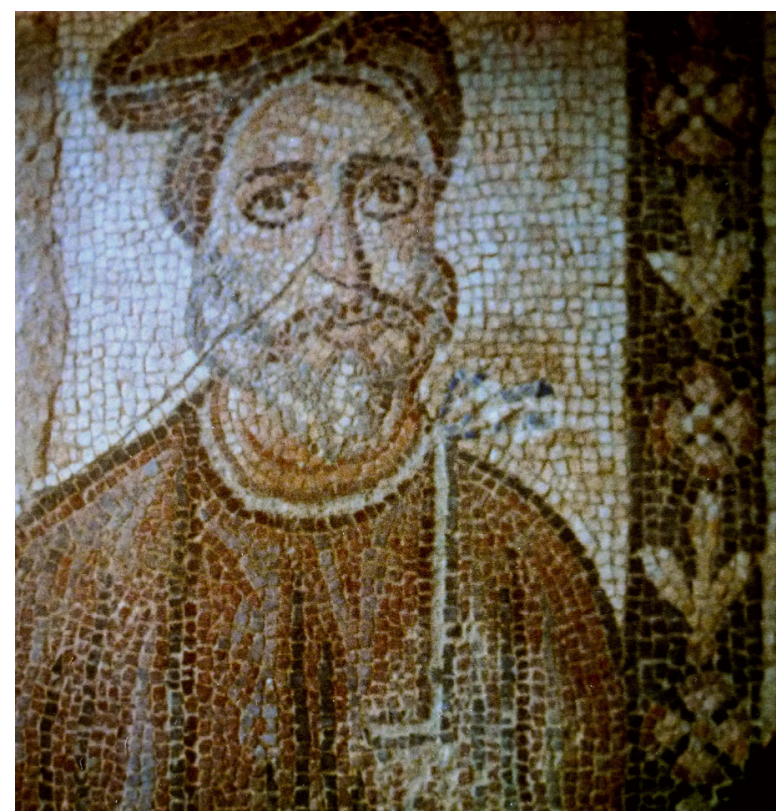

Il. 1. Mozaika z podobizną Maniego (?), III/IV w., zbiory prywatne, fot. P.O. Scholz. 


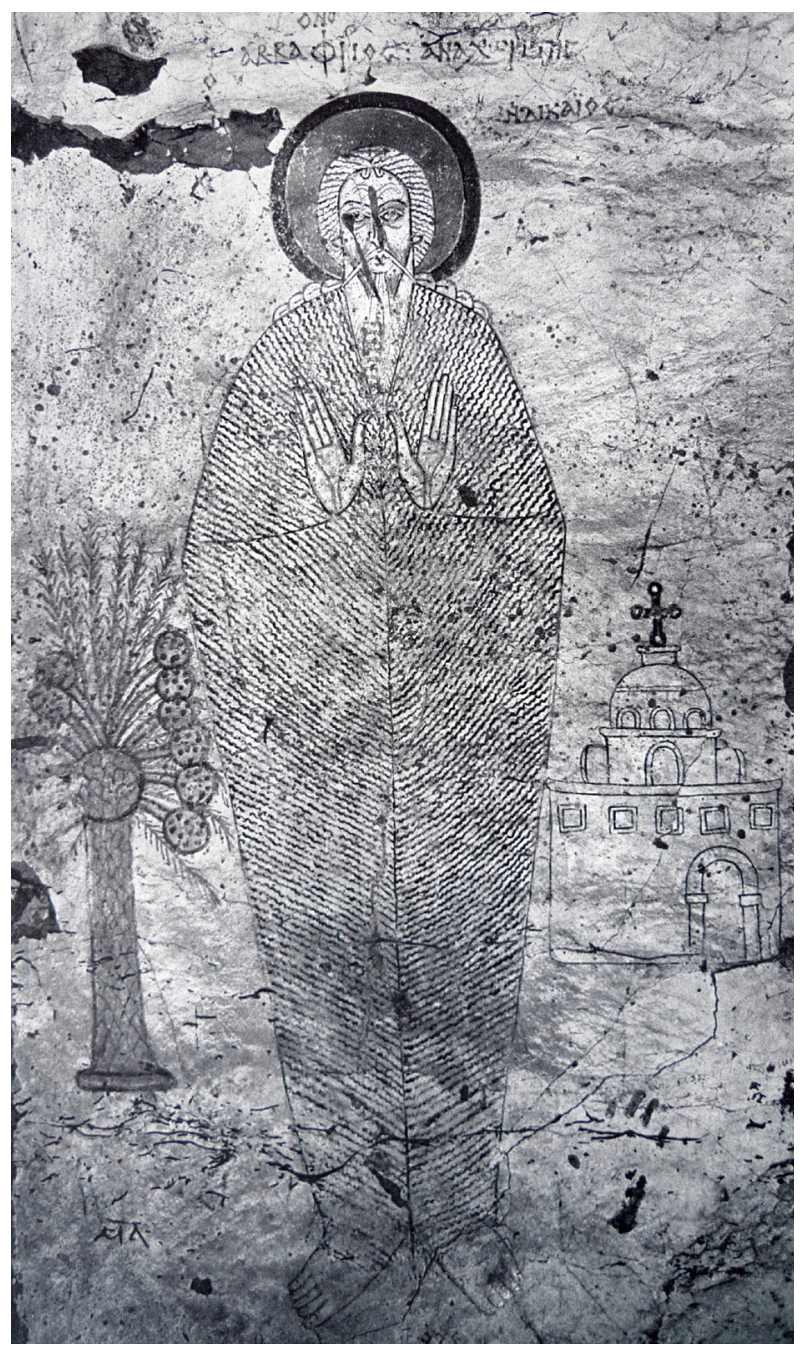

Il. 2. Św. Onufry (Anachorets Onuphrios), malarstwo ścienne z katedry w Faras, datowane na XI w., MN w Chartumie, fot. Georg Gerster. 